\title{
SYRJÄÄN TYÖMARKKINOILTA SYRJÄÄN IHMISYYDESTÄ
}

- hajahavaintoja työttömien koulutuksesta

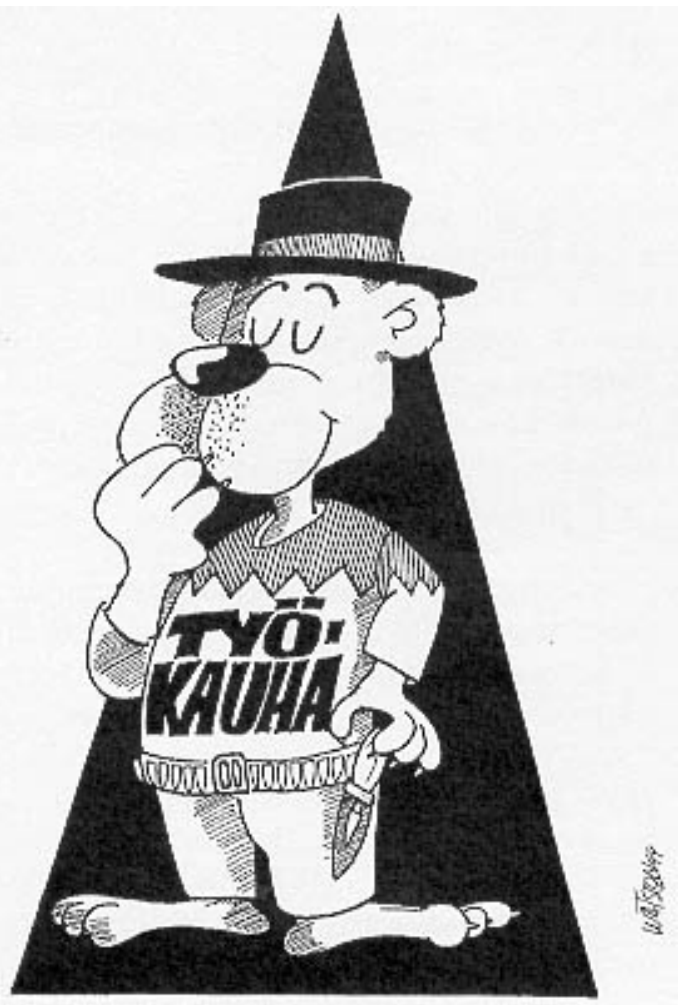

Työväen Sivistysliiton (TSL) opintokeskus aloitti laajamittaisen työttömien koulutuksen vuoden 1992 alusta. Nyt on aika katsoa tuloksia. Yksi projektin tuottama mielenkiintoinen havainto on se, että osallistuminen mihin koulutukseen tahansa näyttää lisäävän työllistymisen tai pidempikestoiseen koulutukseen hakeutumisen todennäköisyyttä. Tärkeää ei siis ole mitä teet, kunhan vain teet jotakin.

Mutta projektin vastaavat ovat joutuneet venymään kynnysmatoiksi milloin minkin viranomaistahon ovelle, välistä masentavin, välistä musertavin kokemuksin. Julkinen valta ja erityisesti työhallinto näyttää lähteneen ja lähtevän edelleen siitä, että vain oppilaitosten kiviseinien sisällä tapahtuva koulutus on tukemisen arvoista.

Työväen Sivistysliiton opintokeskuksen vuonna 1992 käynnistämä työttömien koulutus laajentui nopeasti niin, että vuoden 1994 aikana toteutimme työttömille suunnattua koulutusta jo lähes 21500 opetustuntia. Näiden lisäksi projektiemme yhteyteen syntyi lähes 320 opintokerhoa, joista opintokerhotunteja kertyi yli 11 000 tuhatta.

Projekteissa järjestettiin lukuisia luento- ja tiedotustilaisuuksia ja eri tilaisuuksiimme osallistui yli 30000 työtöntä, pidempikestoiseen koulutukseenkin yli 10 000. Pisimmillään koulutus on kestänyt syksystä kevääseen.

Toimihenkilöjärjestöjen Sivistysliiton (TJS) opintokeskus liittyi projektiin vuoden 1994 alusta ja toi kauttaan kiinteämmät kytkennät myös toimihenkilökenttään.

Valitettavasti emme resurssien puutteen vuoksi ole voineet kytkeä koulutuksen laadun ja vaikuttavuuden systemaattista seurantaa osaksi toimintaa, joten tilastollisia mittareita lukuunottamatta muu arviointi on mutupohjaista ja perustuu hajanaisiin havaintoihin.

Tänä keväänä olemme käynnistäneet väitöskirjatasoisen seurannan työttömien omaehtoisen koulutuksen vaikuttavuudesta ja uskomme ensimmäisten tuloksien olevan käytössä jo loppusyksyllä. 


\section{Koulutuksen organisoinnista}

Olemme perustaneet Työn Suomi -projektille paikallisia osaprojekteja, joiden kautta organisoidaan paikallinen koulutus. Tiloja olemme pääsääntöisesti saaneet kunnilta joko ilmaiseksi tai nimellistä korvausta vastaan.

Projektisihteerit sekä opettajat ovat paikallisia työttömiä, joista osa on palkattu kunnan tai työvoimatoimiston kautta. Suurin osa on kuitenkin palkattu työllistämistukia hyödyntäen TSL opintokeskukseen määräaikaisiin työsuhteisiin.

Opettajina on toiminut runsaasti vastavalmistuneita, jolloin on ollut mahdollisuus käyttää vastavalmistuneiden työllistämistukea. Suuri osa opettajista onkin löytynyt akavalaisten työllistämisprojektien kautta.

Olemme kyenneet tarjoamaan opetustehtävissä oleville jonkin verran myös koulutusta, mutta sen määrä on ollut tarpeeseen nähden riittämätöntä. Tampereella Ahjolan Opisto sekä projektimme TyöPirkka saivat opetushallitukselta kokeilumäärärahaa opettajakoulutuksen järjestämiseen ja kokemukset ovat rohkaisevia.

Erityisesti kielissä ja elämänhallintakoulutuksessa olemme käyttäneet monimuotokoulutusta. Esimerkiksi kielikoulutuksessa olemme antaneet lähiopetusta kolmena päivänä viikossa ja olemme edellyttäneet opiskelijoilta, että he sitoutuvat opiskeluun pienryhmissä lähiopetuksen jälkeen.

Oppilaiden kannalta menetelmä on osoittautunut hyväksi. Pienryhmässä "paremmat" oppilaat ohjaavat "heikommin" oppivia. Kukaan ei putoa ja kukaan ei pitkästy, Keskeyttäminen pidempikestoisessakin koulutuksessa on ollut yllättävän vähäistä.

Ryhmässä työskentely tuo myös kontakteja katkenneiden työyhteiskontaktien sijaan. Monet ilmoittavatkin tämän koulutuksen suurimmaksi ansioksi.

Opettajien kannalta em. menetelmä on työläs, koska se edellyttää normaalia enemmän koulutussisältöjen muokkaamista tehtäviksi. Opetuksen yhteistoiminnallistaminen ja tehtävöittäminen kuitenkin lisää opettajien ammattipätevyyttä.

\section{"Hyviä ja nöyriä" hallintoalamaisia}

Monissa yhteyksissä on korostettu työttömien passiivisuutta ja vaikeuksia saada heitä osallistumaan mihinkään koulutukseen. Kokemuksemme osoittavat nämä väitteet liioitelluiksi. Ongelmana on ollut resurssien, ei oppilaiden puute. Hyvin pienellä tiedotuksella oppilaita on tullut enemmän kuin olemme voineet ottaa vastaan.

Tässä yhteydessä liian vähälle huomiolle on jäänyt myös se, että työttömät on äärimmäisen tehokkaasti peloteltu tekemästä mitään työttömyysaikana. Vaikka olemme sopineet paikallisessa työvoimatoimistossa, että näillä ja näillä edellytyksillä ihmiset voivat opiskella työttömyysturvaansa vaarantamatta, pelko nousee jatkuvasti esille. Eli tältä kannalta katsoen suuret otsikot työttömyysturvan väärinkäytöksistä ovat vähintään liioiteltuja, mutta ovat onnistuneet säikyttämään työttömät perinpohjin.

Tämä näkyy esimerkiksi siinä, että lähes poikkeuksetta yli kolmasosa opiskelijoista ei suostu merkitsemään omaa ammattiliittoaan oppilaslomakkeisiin. Entäpä jos tieto meneekin liiton työttömyyskassalle? Nykyisellään järjestelmä eli laintulkinnat ovat omiaan lisäämään pitkäaikaistyöttömyyden ja syrjäytymisen riskiä pakottamalla ihmiset joutilaisuuteen sanktioitten eli toimeentulon menettämisen uhalla. joissain tapauksissa saattaisi jopa nähdä selkeitä merkkejä ihastumisesta vallankäyttöön. 


\section{Hyvä- ja huono-osaisuus}

Työttömien koulutukseen hakeutumisessa, niinkuin muuallakin yhteiskunnassa, korostuu hyvä- ja huono-osaisuus: ne jotka ovat suurimassa syrjäytymisvaarassa, ovat vaikeimmin koulutuksen keinoin tavoitettavissa. Mitä parempi pohjakoulutus, sitä suurempi todennäköisyys hakeutua omaehtoiseen koulutukseen. Tämä merkitsee myös suurempaa todennäköisyyttä työllistyä - joko koulutuksen avulla tai siitä riippumatta.

Olemme tehneet muutamia hakevan toiminnan kokeiluja tarkoituksena tavoittaa juuri suurimmassa syrjäytymisvaarassa olevia. Kokemukset ovat olleet kahtalaiset: ihmisten liikkeelle saaminen on vaikeaa ja vaatii suuria panoksia. Mutta - kun ihmiset on saatu mukaan, he myös pysyvät mukana pidempikestoisessakin omaehtoisessa koulutuksessa $(2-5 \mathrm{kk})$ ja tällä on erittäin selvä työllistymistä (työnhakuaktiivisuutta) edistävä ja syrjäytymistä ehkäisevä vaikutus.

Toisin sanoen, mikäli yhteiskunta on valmis panostamaan syrjäytymisen ehkäisyyn muutenkin kuin sanoissa, hyvin paljon voidaan tehdä. Erilaiset, esimerkiksi ay-liikkeen verkostoja hyödyntävät hakevan toiminnan järjestelmät tarjoavat tähän erinomaiset mahdollisuudet. Kustannukset esimerkiksi tuotettua opetustuntia kohden nousevat kuitenkin selvästi normaalia suuremmiksi.

Vastapainoksi tulisi tietenkin laskea, mitä yksityisille ihmisille ja yhteiskunnalle maksaa syrjäytyminen ja monet siitä helposti seuraavat ilmiöt: mielenterveysongelmat, perheongelmat, alkoholi, sairastavuuden lisääntyminen...

Tämän hetken painotukset esimerkiksi työvoimapoliittisessa koulutuksessa eivät suosi pitkään työttöminä olleita, huonosti koulutettuja keski-ikäisiä työttömiä eli todellisessa syrjäytymisvaarassa olevia. Panoksia sijoitetaan niihin, joiden uskotaan sijoittuvan suhteellisen nopeasti työelämään. Niukkojen resurssien jakaminen on aina myös arvovalintaa. Tuottavuuden ja tehokkuuden näkökulmasta asiaa katsottaessa, valinta on - lyhyellä tähtäimellä - oikea.

Tästä arvovalinnasta kertovat hyvin edellisen hallituksen linjaukset EU:n sosiaalirahaston rahoituksen jyvityksessä, jossa vain marginaalisesti ollaan sijoittamassa syrjäytymisen estämiseen. ja - kuten sanottua tätä linjausta voidaan perustella mahdollisimman suurella hyödyllä mahdollisimman vähäisillä panoksilla.

Olemme itsekin joutuneet tekemään samansuuntaisia valintoja sekä sisältöjen että kohderyhmien suhteen.

Kuitenkin murto-osalla esimerkiksi työvoimapoliittiseen koulutukseen käytetyistä kustannuksista voitaisiin tehdä Paljon juuri syrjäytymisvaarassa olevien auttamiseksi. Välillä saa sen vaikutelman, että työvoimapoliittisen koulutuksen ensisijainen tavoite on ylläpitää ammatillisten oppilaitosten toimintaa, vasta toissijaisesti tyydyttää työttömien tai työmarkkinoiden tarpeita.

\section{"Hyötykoulutusta"}

Muutama sana koulutuksen sisällöistä; selkeästi suurimmat sisältöalueet, joissa koulutusta järjestettiin, olivat vieraat kielet ja tietotekniikka. Kaikissa työttömille suunnatuissa kyselyissä nämä teemat nousivat esille ensimmäisinä.

Molempien sisältöalueiden kohdalla kävi myös pitkälle ilmi, että osallistujat arvioivat ko. opiskelun tukevan tulevaa työllistymistään. Esimerkiksi kielissä opiskelu turismia varten ei noussut kovin merkittävänä esille. Tämä näkyi selvästi myös kielivalinnoissa alueellisesti: itärajalla painotus on ollut venäjään, länsirajalla ruotsiin. Englanti sekä pienemmässä määrin saksa ja myös ranska ovat olleet suosittuja koko maassa. 
Erilaiset työttömyyteen ja henkiseen hyvinvointiin eli elämänhallintaan liittyvät kurssit ovat myös kiinnostaneet. Selvä enemmistö opiskelijoista on ollut toimihenkilönaisia. Heistä osa, heikon perus- ja/tai ammattikoulutuksen omaavat keski-ikäiset naiset ovat ilmaisseet omana näkemyksenään, etteivät he enää tule työllistymään normaaleille työmarkkinoille ja että he hakevat elämän sisältöä opiskelusta, harrastuksista, järjestötoiminnasta. Tälle realistiselle suhtautumiselle he tavallaan hakevat koulutuksesta siunauksen ja yhteiskunnallisen hyväksynnän: "Kun on niin paljon koulutettuja nuoriakin työttöminä."

Kolmas suurempi sisältöalue on viestintä eri muodoissa. Ihmiset haluavat opetusta puhe- ja esitystaidoissa, kirjallisessa viestinnässä. Viestintään on liittynyt myös selkää työhakukoulutusta. Työnhakutilanne nähdään viestintätilanteena, johon halutaan valmistautua.

Neljäs esiin tuleva alue ovat käden taidot eri muodoissa. Käsityöt, kudonta, puutyöt, metallityöt, mutta myös maalaus, piirtäminen, kuvanveisto... Käden taitojen/taiteellisen ilmaisun harjoittelijoilla on ehkä vähiten pyrkimystä liittää opiskelu ja tulevaisuuden työelämä toisiinsa. Tavoitteena on pikemminkin hyvä elämä kuin työelämä.

Vaikka peruskiinnostus on suuntautunut kieliin ja tietotekniikkaan, koulutustarjonta vaikuttaa ihmisten valintoihin. Tämä on tullut selkeimmin esille Porissa, jossa myös muu kuin kieli- ja tietotekniikkatarjonta on ollut runsainta.

Tietotekniikkakoulutukseen olemme hankkineet runsaasti uudenaikaisia laitteita sekä ohjelmistoja eri puolille maata. Osa tietotekniikkaluokistamme on liikuteltavia. Monin paikoin olemme myös voineet vuokrata vapaana olevia tietotekniikkaluokkia työttömien koulutukseen.

\section{Ikä- ja sukupuoli osallistumisen takana}

Koulutukseen osallistuu kaikenikäisiä ihmisiä, vaikkakin suurten ikäluokkien ihmiset ovat enemmistönä. Nuorten osalla työllistymisnäkökulma näyttää korostuvan erityisesti. Kiinnostuksen kohteiksi ovat nousseet erityisesti kielet ja tietotekniikka. Vanhemmilla painotus on elämänhallinnan ja harrastusten tuen puolella.

Naiset osallistuvat koulutuksen selvästi miehiä enemmän sisältötarjonnan kaikilla alueilla. Suhteessa miehiä kiinnostaa eniten tietotekniikka.

\section{Motivaatiosta}

Edellä on jo todettu, että työttömillä selvästi tärkeimpiä olivat hyötymotiivit: työllistymismahdollisuuksien parantaminen, työssä selviämisen edellytysten parantaminen, sosiaalisten suhteiden solmiminen...

Hyötymotiiviksi voi kai määritellä myös elämänhallintakoulutuksen. Mukaan tulijat eivät ehkä nimeä koulutusta näin, mutta sisältötoiveissa se ilmenee selkeästi.

Mielenkiintoinen havainto, joka kaipaisi perusteellisempaa selvitystä, on se, että osallistuminen mihin koulutukseen tahansa näyttää lisäävän työllistymisen tai pidempikestoiseen koulutukseen hakeutumisen todennäköisyyttä. Tärkeää ei siis ole mitä teet, kunhan vain teet jotakin.

\section{Työpajamestari- ja kisällikokeilu}

Paikalliseen Työlakeus-projektiimme liittyen käynnistimme viime syksynä myös nuorille ja vanhemmille pitkäaikaistyöttömille tarkoitetun työpajakokeilun Seinäjoki-Nurmon alueilla. OPM myönsi hankkeelle 100 000 mk:n avustuksen. 
Kokeilu on edennyt siten, että Seinäjoen ja Nurmon kuntien sekä työhallinnon myötävaikutuksella olemme järjestäneet pajalaisille ohjaavaa koulutusta sekä työtä heinäkuun puoliväliin. Tavoite on, että kaikille löytyisi joko työ- tai koulutuspaikka pajajakson jälkeen. Työjakso on suurin piirtein puolivälissä ja ainakin vielä innostus ja usko tulevaisuuteen on pajalaisten keskuudessa suuri.

\section{Tulevaisuudesta ja ongelmista}

Työttömyys, työttömien oma monipuolinen osaaminen sekä työttömien koulutustarpeet tarjoavat jatkossa mahdollisuuksia hyvin laajaan koulutustoimintaan. Valitettavasti olemme itse joutuneet kevään 1995 aikana ajamaan projekteja ja koulutustoimintaa alas, purkamaan organisaatiota ja päättämään työsuhteita. Syynä siihen on ollut se, että kädenojennukset valtiovallalta ovat olleet vähäisiä. Erityistukea opetushallinnolta emme ole saaneet tuloksista huolimatta. Erittäin musertavana koimme vuoden 1993 lopulla tehdyn päätöksen, jonka mukaan vapaan sivistystyön laitokset suljettiin lääninhallitusten koulutusostojen ulkopuolelle. Tällä päätöksellä estettiin kymmenien tuhansien opetustuntien toteuttaminen, satojen opettajien työllistäminen sekä kymmenien tuhansien työttömien koulutus.

Vaikka kysymys on omaehtoisesta toiminnasta, se ei näytä toimivan pelkästään työttömien oma-aloitteisten virikkeiden ja tarpeiden pohjalta, vaan tarvitaan organisaatio toimintaa synnyttämään, ylläpitämään ja kehittämään. Vapaan sivistystyön laitokset ovat "kevytrakenteisina" ja joustavina omiaan tähän tehtävään.

Edelleen kohderyhmästä, opetusmuodosta sekä kestoista seuraa tarpeita opettajien koulutukselle sekä opetuksen suunnittelulle. Tätä ei voida hoitaa vasemmalla kädellä. Muutoin syyllistymme kohderyhmän, asiakkaiden halveksuntaan.

\section{EE UU - ei tuu}

Suuntasimme suuria odotuksia EU:n sosiaalirahaston mahdollisuuksiin tukea em. toimintaa. Olemmekin saaneet runsaasti kannustusta, kiitosta - ja lupauksia. Tähän sopisi hyvin vanha sanonta: "On sitä tien neuvojaa - vaan onko palan antajaa?" Palan antajat ovat olleet vähissä ja sosiaalirahaston tuki näyttää joko viipyvän tai menevän "tärkeimpiin" kohteisiin. Eli ennen kurki kuolee kuin suo sulaa.

Kuitenkin koulutus, jota olemme tarjonneet näyttäisi soveltuvan erityisen hyvin kansallisesti asetettuihin tavoitteisiin, esimerkiksi tavoite 3: pitkäaikaistyöttömyyden torjuntaan, nuorten integroimiseen työmarkkinoille sekä syrjäytymisen ehkäisyyn. Edelleen työttömien koulutussisällöt palvelevat myös tavoitteen 4 päämääriä, "työssä olevan väestön kouluttaminen ammatti- sekä elinkeinorakenteen muutoksiin".

Useimmat tavoitteen yhteydessä kirjatuista sisällöistä ovat sellaisia, joita olemme tarjonneet työttömien koulutuksessa uskoen niillä olevan merkitystä työllistymiselle. ja useat sisällöistä ovat sellaisia, joita opintokeskukset ja muu vapaan sivistystyön laitokset ovat tottuneet tuottamaan. Kuitenkin julkinen valta ja erityisesti työhallinto näyttää lähteneen ja lähtevän edelleen siitä, että vain oppilaitosten kiviseinien sisällä tapahtuva koulutus on tukemisen arvoista. Siitä riippumatta, mitä se maksaa.

Viranomaiset ovat myös kehittäneet hyvän tavan pompotella hankkeittemme tukea toteamalla sen itse asiassa kuuluvan (päättäjästä riippuen) opetus-/ työ-/sosiaali- ja terveysministeriön tuettavaksi. Toiminnan kaikki myöntävät järkeväksi ja peräti tarpeelliseksi.

Sadasosalla työvoimapoliittiseen koulutukseen suunnatuista varoista vapaan sivistystyön kautta voidaan tuottaa nykyiseen verrattuna kymmenkertainen määrä opiskelua. Kysymys on tahdosta, ei rahasta!

Olemme pieni kansa, jonka tärkein voimavara on hyvin koulutettu väestö. Siksi meillä ei ole varaa makuuttaa satoja tuhansia ihmisiä tyhjän panttina odottamassa kutsua työhön, jota monelle ei koskaan tule. 
Meidän on pikemminkin kaikin tavoin tuettava ihmisten kaikinpuolista kouluttautumista tulevaisuuden haasteita varten, kohdattiinpa ne sitten työelämässä tai muualla yhteiskunnassa. 